\title{
Drinking water quality analysis after 22 deaths in LaeMaromas, North Sumatera
}

\author{
Abraham Simatupang ${ }^{1 *}$, Seruni Kusuma Udyaningsih Freisleben ${ }^{2}$, Maruli Pandjaitan ${ }^{3}$, \\ Christel Westerhausen ${ }^{4}$, Hans-Joachim Freisleben ${ }^{5}$ \\ 'Department of Pharmacology and Therapy, Faculty of Medicine Universitas Kristen \\ Indonesia, Jakarta; ${ }^{2}$ Department of Physica, Faculty of Mathematics and Natural Sci- \\ ences Universitas Indonesia, Jakarta; ${ }^{3}$ Swiss German University, EduTown BSD City, \\ Serpong Tangerang, ${ }^{4}$ Tarutung District Hospital, Tarutung, North Sumatera Province, \\ ${ }^{5}$ Medical Research Unit, Faculty of Medicine, Universitas Indonesia, Jakarta
}

\section{ABSTRACT}

The case of 22 deaths in LaeMaromas, North Sumatera suspected due to water contamination by nearby metal mining was brought by local citizens to the Church-supported non-governmental organization (NGO) Persekutuan Diakonia Pelangi Kasih (PDPK). The patients' clinical symptoms were fever, shivering, shaking chills, abdominal pain, diarrhoea, and vomiting. In June 2011, a team from the District Health Department analysed the drinking water quality, especially microbiological contamination. Members of PDPK asked the German-Indonesian Medical Association to conduct a second complete water analysis with focus on heavy metal content. Six water samples from four different wells in LaeMaromas and two from Sopokomil and Bongkaras were analysed according to international water quality standards. Taste, odour, colour, and turbidity were determined by organoleptic and photometric methods. Temperature and $\mathrm{pH}$ were measured with a calibrated thermometer and $\mathrm{pH}$-meter. Total dissolved solids were determined gravimetrically, hardness as $\mathrm{CaCO}_{3}$ content. Inorganic anions and nitrogen compounds were measured by titration. Contamination with Eschericia coli and coliform bacteria, organic compounds and detergents was determined according to standard methods. Heavy metals were measured by atomic absorption spectroscopy. The $\mathrm{pH}$ of the water (4.5-6.5) was below standard (6.5-8.5). Heavy metals were within the allowed concentrations. All samples from LaeMaromas contained high counts coliform bacteria /E. coli with a peak of 1600 counts $/ 100 \mathrm{~mL}$ and high organic compound level of $63 \mathrm{mg} / \mathrm{L}$ in LaeMaromas III. Most probably, the 22 deaths were caused by drinking water contamination with coliform bacteria rather than by heavy metals or other chemicals.

\section{ABSTRAK}

Kasus kematian 22 orang di desa LaeMaromas, Sumatera Utara, yang diperkirakan karena limbah pertambangan emas, air raksa dan seng mendorong penduduk lokal melaporkannya kepada organisasi masyarakat setempat dan Persekutuan Diakonia Pelangi Kasih (PDPK). Gejala klinis yang timbul adalah demam, menggigil, nyeri perut, diare, dan muntah. Bulan Juni 2011 Dinas Kesehatan Medan menganalisis kualitas air di desa LaeMaromas, khusus terhadap kuman penyakit. Anggota PDPK minta analisa air diulang oleh tim kumpulan Dokter Indonesia Jerman untuk melakukan penelitian kandungan mineral air. Enam contoh air berasal dari 4 sumur yang berbeda di desa LaeMaromas dan dua dari Sopokomil serta Bongkaras dianalisis menurut standard internasional pemeriksaan baku mutu air. Rasa, bau, dan warna serta turbiditas ditentukan dengan cara organoleptik atau fotometrik. Suhu dan $\mathrm{pH}$ dengan termometer serta $\mathrm{pH}$-meter, sedangkan total benda padat yang terlarut secara gravimetri. Kebasaan air diukur dalam $\mathrm{CaCO}_{3}$, sedangkan anion anorganik klorida, fluorida, sulfat, sianida, dan senyawa nitrogen seperti amonia, nitrat dan nitrit ditentukan dengan cara titrasi. Logam berat dan logam transisi diukur dengan spektroskopi serapan atom. Kontaminasi terhadap E. coli, komponen organik dan deterjen juga diperiksa. Keasaman air ada di semua lokasi LaeMaromas $(\mathrm{pH}$ 4.7-6.5, standard: 6.5-8.5). Kandungan logam berat

\footnotetext{
* corresponding author: bram.simatupang@gmail.com
} 
dalam batas standard yang diperbolehkan. Semua contoh air dari LaeMaromas terkontaminasi bakteri koliform, bahkan di LaeMaromas III nilainya $>1600$ bakteri/100 mL demikian pula kandungan materi organiknya $63 \mathrm{mg} / \mathrm{L}$. Penelitian ini menunjukkan penyebab kematian 22 orang di desa LaeMaromas kemungkinan karena tingginya kandungan bakteri coliform di air, sedangkan kecurigaan akan kontaminan yang berasal dari pertambangan tidak terbukti.

Key words: sanitation - E. coli - water contamination - heavy metals - mortality

\section{INTRODUCTION}

The area, from where 22 deaths were reported, is in the vicinity of Parongil and Sopokomil, about 15-20 km from SidikalangDairi, mainly inhabited by Batak ethnics. The two dwellings of the village LaeMaromas, where the illness occurred and where 70 families with 200 persons are living, can be reached from there, after 2 hours of walking. The village is located in an area of 27,420 hectares at a mountain with reserved forest. At the foot of the mountain, water is collected from 6 sources and led via pipes to 6 water outlets in the village.

In higher regions of the mountain, mining companies dug down to $1200 \mathrm{~m}$ deep in order to exploit gold, mercury and zinc. To this end, chemicals were used like Austrol, Auszel, Auspolimer (Telor) at amounts of 50-100 litres per day. The companies were from the USA and Australia; permits were obtained from the Indonesian Ministry of Development.

Until 2006, LaeMaromas was free from special endemic diseases. The first case in 2006 was a worker at the mining project. One mining shift comprised 30 workers: 10 mining specialists and 20 helpers, the latter being locally recruited. The mining personnel did not drink water from the mountain, but rather bottled drinking water, which was transported to the mining plant via helicopters.

Villagers reported that the ground had become hard on their fields, rice production decreased, banana plants, and durian trees became dry and burnt, and fish in the ponds were less in numbers. Two villagers reported especially about the sickness, one of them a man, who had been ill for 3 months with repeated attacks. Furthermore, the Catholic preacher of the respective area reported and two co-workers of a project, which was supported by the German Protestant Development Service. All reports were collected by one of us (Christel Westerhausen), who served as a gynaecologist in the District Hospital of Tarutung during this time.

Between 2006 and 2008, the disease commenced with fever, shivering and shaking chills, abdominal pain, diarrhoea, and vomiting. In all cases, the appearance and the course of the sickness were similar. The closest Pusat Kesehatan Masyarakat (Community Health Centre) - managed by a midwife - delivered up to 5 glucose-PBS infusions per patient. In most cases, the duration of the sickness was two weeks. One patient survived after 3 months with repeated attacks and 16 infusions.

During the first phase, 9 patients died and during the second phase, seven patients comprising small children and adults. From November 2010 to April 2011, 6 patients died, among them two children aged 18 months. A child aged 30 months suffered from exudative otitis accompanied by relapsing pyodermic infections, especially in surrounding (periauricular) skin areas of its head. Improvement was achieved after long-term therapy including topical skin treatment. Unfortunately, we could not obtain any information about specific details of this therapy. 
Because of the alarming news in the tabloids, the Head of District (Bupati) visited the area with a health service team. Blood from 187 villagers was investigated, 68 were positive for malaria. According to the reports, a health team from the Catholic Church including a medical practitioner and a medical team from UI were not allowed to enter the respective area.

In 2012, mining was discontinued in the area and the diseases decreased and eventually disappeared. In total, 22 deaths had been reported, young children, adolescents, and adults in Lae Maromas with unclear reasons. Water polution and malaria infection were discussed as the background of these deaths on 31 August 2011 with members of Persekutuan Diakonia Pelangi Kasih (PDPK), a local civil society organization. It was assumed that a reason could be water pollution because of mining companies operating in the vicinity of the village. Connections were made to the German-Indonesian Medical Association (DIGM) in September 2011 with the question to investigate water samples from the six water outlets in the villages.

In June 2011, the Health Department RI in Medan had conducted a drinking water analysis, but according to the members of PDPK, heavy metal contents in the drinking water of the village of Lae Maromas had not been measured. Hence, we decided to complete the measurement of water quality in the laboratories at University of Indonesia, Department of Physics Faculty of Mathematics and Natural Sciences, in the accredited commercial service laboratory TRAS in Jakarta-Pondok Gede, and in the accredited Water Laboratory of the SwissGerman University (SGU) in Serpong.

\section{MATERIALS AND METHODS}

Six water samples from different wells, four in LaeMaromas Village and one each from Sopokomil and Bongkaras were investigated according to international routine water quality standards. ${ }^{1-4}$ Measurements were conducted in the laboratories of the Province Health Department in Medan, the Department of Physics Faculty of Mathematics and Natural Sciences, Universitas Indonesia, Jakarta, in the accredited commercial service laboratory TRAS in Jakarta-Pondok Gede, and in the Water Laboratory of the SwissGerman University (SGU) in Serpong.

The investigations were coordinated by DIGM: Abraham Simatupang as member of the Indonesian Section, Christel Westerhausen and Seruni K.U. Freisleben (SKUF) as members of the German Section, and Hans-Joachim Freisleben (HJF) as the current President of the German Section (DIGM e.V.). Laboratory measurements were coordinated and/or conducted by SKUF, HJF, and Maruli Pandjaitan.

General measurements of odor, taste, color (true color units, TCU), turbidity (nephelometric turbidity units, NTU) were determined by organoleptic or photometric/nephelometric standard methods, temperature and $\mathrm{pH}$ with calibrated thermometer and $\mathrm{pH}$-meter, total dissolved solids (TDS) gravimetrically (mg/L).

Hardness was measured as $\mathrm{CaCO}_{3}(\mathrm{mg} / \mathrm{L})$, inorganic anions chloride, fluoride, sulphate, and cyanide and nitrogen compunds ammonia, nitrate and nitrite were determined by titration.

Heavy metals and transition metals, Fe, Zn, $\mathrm{Mn}, \mathrm{Cr}, \mathrm{Hg}, \mathrm{Cd}, \mathrm{Pb}$ and Arsenium were measured by atomic absorption spectroscopy (AAS) with a Varian SpetrAA.30 and GTA.96 with a Data Station (Varian, Austria) connected - against standard solutions from Merck AG, Darmstadt or Riedel-de Haën, Germany. The procedures followed the manual instructions provided by Varian, Austria.

Microbiological contamination, total coliform and E. coli, total organic compounds and detergents were measured in the Laboratory of Health Department Republic of Indonesia in Medan. 


\section{RESULTS}

General parameters of drinking water quality are shown in TABLE 1. Color was above the limit of 15 TCU in two samples, 18.8 and 23.7 and $\mathrm{pH}$ was more acidic than the standard range of 6.5-8.5 in three samples, one sample just at the limit. It was indicated that the drinking water obtained and investigated in LaeMaromas was very acidic in all 4 samples. Whereas the two samples, one from Sopokomil and one from Bongkaras, were close to the alkaline standard limit of 8.5, i.e., 8.3 and 8.4, respectively. All other general values were within the standard limits. The values exceeding the limits were not endangering human lives. They were mostly “desirable standards”, i.e., not strict limits. ${ }^{1-4}$

TABLE 1. General parameters of drinking water quality

\begin{tabular}{|c|c|c|c|c|c|c|c|}
\hline \multirow{2}{*}{$\begin{array}{l}\text { Parameter/ } \\
\text { Substance }\end{array}$} & \multicolumn{4}{|c|}{ LacMaromas } & \multirow{2}{*}{ Sopokomil } & \multirow{2}{*}{ Bongkaras } & \multirow{2}{*}{ Standard } \\
\hline & I & II & III & 0 & & & \\
\hline Odor & odorless & odorless & odorless & odorless & odorless & odorless & odorless \\
\hline Taste & tasteless & tasteless & tasteless & tasteless & tasteless & tasteless & tasteless \\
\hline $\begin{array}{l}\text { Temperature } \\
\left({ }^{\circ} \mathrm{C}\right)\end{array}$ & $26-27$ & $26-27$ & $26-27$ & $26-27$ & $26-27$ & $26-27$ & $\begin{array}{l}\text { Air temperature } \\
3\end{array}$ \\
\hline $\begin{array}{l}\text { Total dissolved } \\
\text { solids/TDS } \\
\text { (mg/L) }\end{array}$ & $6-30$ & $4-10$ & $4-30$ & $3-50$ & 200 & 190 & 500 \\
\hline Color (TCU) & 12.8 & 18.8 & 14.5 & 23.7 & n.d. & n.d. & 15 \\
\hline Turbidity (NTU) & 2 & 1 & 1 & $<1$ & n.d. & n.d. & 5 \\
\hline pH & $4.7-5.8$ & $4.8-5.9$ & $5,0-5.8$ & $6.2-6.5$ & 8.3 & 8.4 & $6.5-8.5$ \\
\hline $\begin{array}{l}\text { Hardness } \\
\left(\mathrm{mg} / \mathrm{L} \mathrm{CaCO}_{3}\right)\end{array}$ & $12-80$ & $8-56$ & $5-72$ & $6-64$ & 145 & 134 & 500 \\
\hline
\end{tabular}

TDS: total dissolved solids; TCU: true color units; NTU: nephelometric turbidity units; n.d.: not determined.

All inorganic anions (acids) measured were in the standard range (TABLE 2), also nitrogen containing acids and ammonium were in the normal range. The most toxic compound in this group, cyanide was at least one magnitude below the limit. Only one value, flouride in LaeMaromas sample I (= $1.53 \mathrm{mg} / \mathrm{L})$ was just over the limit of $1.5 \mathrm{mg} / \mathrm{L}$, but certainly not in a dangerous, life-threatening concentration. 
TABLE 2. Inorganic anions and nitrogen compounds

\begin{tabular}{|c|c|c|c|c|c|c|c|}
\hline \multirow{2}{*}{ Compounds } & \multicolumn{4}{|c|}{ LaeMaromas } & \multirow{2}{*}{ Sopokomil } & \multirow{2}{*}{ Bongkaras } & \multirow{2}{*}{ Standard } \\
\hline & I & II & III & 0 & & & \\
\hline \multicolumn{8}{|l|}{ Inorganis anios } \\
\hline - Chloride (mg/L) & $1.38-72.92$ & $5.9-72.92$ & $0.98-60.05$ & $0.98-60.05$ & 60.05 & 60.05 & 250 \\
\hline - Fluoride (mg/L) & 1.53 & $<0.01$ & 0.08 & 0.10 & n.d. & n.d. & 1.5 \\
\hline - Sulphate (mg/L) & $1.24-14.8$ & $0.72-12.6$ & $1.24-28.4$ & $2.06-24.8$ & 1.24 & 1.85 & 250 \\
\hline \multicolumn{8}{|l|}{ Nitrogen } \\
\hline - Nitrate (mg/L) & 0.3 & 0.7 & 0.6 & 0,8 & n.d. & n.d. & 50 \\
\hline - Nitrite (mg/L) & 0.0081 & 0,0015 & 0.0061 & 0,0327 & n.d. & n.d. & 3 \\
\hline - $\mathrm{NH}_{3}(\mathrm{mg} / \mathrm{L})$ & $\infty 0.001$ & $<0.001$ & $\$ 0.001$ & $<0.001$ & n.d. & n.d. & 1.5 \\
\hline - Cyanide (mg/L) & 0.005 & 0.004 & 0.006 & 0.007 & n.d. & n.d. & 0.07 \\
\hline
\end{tabular}

n.d.: not determined

All inorganic cations, transition metals and heavy metals measured were in the standard range (TABLE 3), except for one single measurement (LaeMaromas sample 0) which showed a result of $0.023 \mathrm{mg} / \mathrm{L} \mathrm{Pb}$ at a standard limit of $0.01 \mathrm{mg} / \mathrm{L}$. However, since all other measurements from the same water sample were 0 , the value of $0.023 \mathrm{mg} / \mathrm{L}$ can for sure be eliminated as an instrumental error. However, even if all measurents from this sample were calculated, the average value was $0.0008 \mathrm{mg} /$ $\mathrm{L}$, which was more than one magnitude below the standard limit. Arsenic was only found in two samples with values below the limit. ${ }^{6}$
Special attention needs chromium-VI (TABLE 3), which is pathophysiological the most problematic oxidation state of all chromium compounds. European and NorthAmerican water guidelines do not contain specific $\mathrm{Cr}^{\mathrm{VI}}$ limit values; hence, total chromium limits apply. However, there are aims for future water guidelines revisions to allow a maximum of $0.05 \mathrm{ppb} \mathrm{Cr}^{\mathrm{VI}}$ in drinking water. ${ }^{2,4,5}$ Hence, the detected values of $\mathrm{Cr}^{\mathrm{VI}}$ met the current limits, but not the future aims of international organizations. 
TABLE 3. Inorganic cations and heavy metals

\begin{tabular}{|c|c|c|c|c|c|c|c|}
\hline \multirow{2}{*}{$\begin{array}{l}\text { Inorganic } \\
\text { cations }\end{array}$} & \multicolumn{4}{|c|}{ Lae Maromas } & \multirow{2}{*}{ Sopo komil } & \multirow{2}{*}{ Bong karas } & \multirow{2}{*}{ Standard } \\
\hline & I & II & III & 0 & & & \\
\hline $\mathrm{Fe}(\mathrm{mg} / \mathrm{L})$ & 0.214 & 0.314 & 0.083 & 0.142 & nd. & n.d. & 0.3 \\
\hline $\mathrm{Zn}(\mathrm{mg} / \mathrm{L})$ & 0.004 & 0,007 & 0.012 & 0.009 & 0.021 & 0.024 & 3 \\
\hline $\mathrm{Mn}(\mathrm{m} / \mathrm{L})$ & 0.001 & 0.004 & 0.006 & 0.006 & nd. & n.d. & 0.4 \\
\hline $\mathrm{Cr}^{\mathrm{NT}}(\mathrm{ppb})$ & 0.008 & 0,006 & 0,048 & 0,032 & nd. & n.d. & $0.05^{*}$ \\
\hline $\mathrm{Hg}(\mathrm{ppb})$ & 1.44 & 1.47 & 1.73 & 1.64 & 1.57 & 1.47 & $6 / 2 * * *$ \\
\hline $\mathrm{Cd}(\mathrm{ppb})$ & 0.06 & 0.18 & 0.01 & 0.0 & 0.21 & 0.08 & 3 \\
\hline As (ppb) & 0.664 & 0 & 0 & 0 & 0 & 3.24 & 10 \\
\hline $\mathrm{Pb}(\mathrm{mg} / \mathrm{L})$ & 0 & 0 & 0 & $\begin{array}{c}0-0.0008 \\
(0.023)\end{array}$ & 0 & 0 & 0.01 \\
\hline
\end{tabular}

* see special attention to chromium in the text; 6 according WHO \& 2 according USA

TABLE 4 shows the obvious reason of the deaths in LaeMaromas village. There was a considerable contamination with coliforms in all 4 samples from LaeMaromas, and contamination with E. coli in three of four samples. Sample LasMaromas III was contaminated at such tremendous extent $(>1600$ counts $/ 100 \mathrm{~mL}$ ) that also the value of total organic compounds was increased (63 mg/L). All tested detergents were in the normal range.

TABLE 4. Organic compounds and microbiological contamination

\begin{tabular}{|c|c|c|c|c|c|c|c|}
\hline \multirow{2}{*}{ Contaminants } & \multicolumn{4}{|c|}{ LaeMaromas } & \multirow{2}{*}{ Sopokomil } & \multirow{2}{*}{ Bongkaras } & \multirow{2}{*}{ Standard } \\
\hline & I & II & III & 0 & & & \\
\hline \multicolumn{8}{|l|}{ Oraganis compounds } \\
\hline - Total (mg/L) & 3.2 & 3.2 & 63 & 5.7 & n.d. & n.d. & 10 \\
\hline - Detergents (mg/L) & 0.018 & 0.010 & 0.016 & 0.010 & n.d. & n.d. & 0.05 \\
\hline \multicolumn{8}{|l|}{ Microorganisms } \\
\hline - Total coliform $\left(100 \mathrm{~mL}^{-1}\right)$ & 79 & 48 & $>1600$ & 220 & n.d. & n.d. & 0 \\
\hline - E. coli $\left(100 \mathrm{~mL}^{-1}\right)$ & 22 & 0 & 5.6 & 2 & n.d. & n.d. & 0 \\
\hline
\end{tabular}

n.d.: not determined

\section{DISCUSSION}

The question arose and was discussed whether the reason of the 22 deaths in LaeMaromas village could have been increased concentrations of heavy metals or poisonous compounds in the drinking water. The background for this assumption was that in the area of the village mining companies were 
operating. The first result from the laboratory of Medan (TABLE 4) had shown the microbiological contamination as the reason of the reported deaths, but had not disclosed results about pollution with inorganic compounds, especially heavy metals.

Furthermore, the behavior of some officials in the area, who obviously refused access to the village area for a groups of scientists and physicians from the Faculty of Medicine Universitas Indonesia increased suspicion among the inhabitants and the curiosity in PDPK. Only full water analysis could clarify these questions.

The outcome of the water analysis in Depok and Bumi Serpong Damai (BSD) showed that there was no reason to suspect heavy metals or inorganic acids and especially nitrogen compounds as the reasons of the deaths in LaeMaromas. As for the heavy metals and transition metals measured, we used the normal tab water from the laboratory of the Department of Physics FMIPA UI as a comparison. As an example, the values in Depok for $\mathrm{Pb}$ and $\mathrm{Cd}$ were 20-50 times higher than the values in the samples from the village area. That means, if the water from the laboratory tab is also used as drinking water, the students and staff at UI in Depok are much more endangered through heavy metal poisoning than the villagers in LaeMaromas.

On the other hand, the results from contamination with $E$. coli and coliforms speak for insufficient separation of the drinking water wells from waste water from the village, which is directly contaminated with human-pathogenic feces germs. ${ }^{7}$

If the contamination originates from animals such as from animal farms or husbandry, pollution with nitrogen compounds should be detectable too. However, all nitrogen compounds (NH3, nitrate, nitrite) are in the normal range, which speaks for contamination from human origin (river latrines, night soil). ${ }^{8}$ Problems of increased chloride and nitrate levels in drinking water in Tanzania had been reported and discussed, recently. ${ }^{9}$

Another nitrogen-containing weak inorganic acid, cyanide is highly poisonous to humans and often used in metal leaching processes. However, also this compound is in a very low range, at least one magnitude below the standard limit. To elucidate the problems of acute gastrointestinal illness (AGI) in connection with drinking water, which may account to the 22 deaths reported and discussed here, it may be important to point out that 4.26-11.69 million cases of AGI are annually attributable to public drinking water systems even in an advanced country as the United States. ${ }^{10}$

\section{CONCLUSION}

After intensive drinking water analysis in three different laboratories, the reported deaths in LaeMaromas can only be ascribed to microbiological contamination, probably because of insufficient separation of village sewage and drinking water sources.

\section{ACKNOWLEDGEMENTS}

The drinking water analysis of the organic compounds and the microbiological contamination was accomplished in the Laboratory of KEMKES RI in Medan. The authors are grateful to the Health Department Republik Indonesia in Medan, to Dr. Aswar Manaf, Department of Physics Faculty of Mathematics and Natural Sciences UI in Depok and to the Swiss-German University (SGU) in Bumi-Serpong-Damai, where measurements were conducted and facilities were generously provided. As far as necessary, where public funding was insufficient, reagents and other 
laboratory costs were privately financed by SKUF and HJF.

\section{REFERENCES}

1. Deutsche Trinkw V. German drinking water regulations, which are under permanent revision. [cited 2012, October 15]. Available from: http:// www.umweltbundesamt.

2. UN-Water Global Analysis and Assessment of Sanitation and Drinking-Water (GLAAS) 2012 Report: the challenge of extending and sustaining services. World Health Organization. Geneva, 2012.

3. WHO/UNICEF. Progress on Drinking Water and Sanitation: 2012 Update. WHO/UNICEF Joint Monitoring Programme for Water Supply and Sanitation. New York, 2012.

4. Bartram J, Corrales L, Davison A, Deere D, Drury D, Gordon B, Howard G, Rinehold A, Stevens M. Water safety plan manual: step-by-step risk management for drinking water suppliers. World Health Organization. Geneva, 2009.

5. Varian manual AAS - Varian atomic absorption AA240FS instructions. User Guide March 16,
2010. Latest version retrieved from Oxford University MChem on April 7, 2013.

6. US EPA. 2006. Arsenic in drinking water. http:// www.epa.gov (last update March 6, 2012)

7. Freisleben H-J, Harjani Purwanegara D, Imam Supardi H. Microbiological aspects in water quality guidelines. SUDR-Project, Bandung, Indonesia, 1994.

8. Balai Penelitian Tanah. Analisis Kimia Tanah, Tanaman, Air, dan Pupuk. Badan Penelitian dan Pengembangan Pertanian Departemen Pertanian. Bogor, Indonesia, 2005.

9. Napacho ZA, Manyele SV. Quality assessment of drinking water in Temeke District (part II): Characterization of chemical parameters. African J. Environ. Science Technol. (AJEST) 2010;4(11):775-89. Available online at http:// www.academicjournals.org/AJEST

10. Colford JM, Roy S, Beach MJ, Hightower A, Shaw SE, Wade TJA. Review of household drinking water intervention trials and an approach to the estimation of endemic waterborne gastroenteritis in the United States. J. Water Health 2006; 4:7188. 